\title{
Towards Catholic Action in pre-war Poland. Creating new one on traditional bases
}

The reactivation of the Catholic Action (CA) in Poland, which ended its activity in 1939, would have not been possible without the pre-war structures of this secular Catholic organization. Although the break in the existence of this organization in Poland lasted nearly 60 years, but the old form of activity, program and many of its works encouraged the Polish Church, by the initiative of John Paul II, to revive this entity. This article outlines the ideological basis for the creation of the first Catholic Action in the world. Its main organizational forms are also presented in the article, and at the same time, the similarity between the pre-war structures of CA in Poland and their Italian prototype. The last part of the paper outlines the process of creating pre-war structures of the Catholic Action in Poland, its legal basis and areas of activity. Althaough after the Second Vatican Council, there was another perception of the laity in the world, and its role in the Church increased, but the pre-war Catholic Action became a basis for creating a new organization in Poland. The reactivated Polish CA took on a rather traditional model, preserving the institution of the Church assistant as a secular liaison with the hierarchy of the Church.

Key words: Catholic Church, Catholic Action, Poland, lay people, Holy See.

The name of Catholic Action (CA), which currently has 20 thousand members in Poland, ${ }^{1}$ was used for the first time in a document called "Moto proprio" of Pope Pio X in 1903. He defined in this way all apostolic activity of Catholics. In that time the hierarchy of the Church was considering catholic action not as an organization, but as an activity of 
Catholics. Over time it became an institutional reality and an alternative for the lower classes, which in two firsts decades of XX century were clearly susceptible to leftiest ideologies, including communism.

The first structures of Catholic Action were created in Italy in 1923. Seven years later Catholic Action was founded in Poland, but the organization worked there only till the beginning of the II World War. Afterwards CA did not receive permission for activity from the Polish communist governments. The idea of its reactivation appeared in the first years of 90 s. It came back to life in 1996 , but having different form than the pre-war organization.

The Second Vatican Council (Vaticanum II), which took place in Rome between 1962 and 1965, brought important changes for Catholic Action. During this occasion bishops accepted many changes about the laity in the Catholic Church doctrine. According to the new rules Catholic Action was not anymore privileged among other lay organizations. Vaticanum II abolished obligatory mandate which before Catholic Action had been used to receive from hierarchy of the Church.

According to the statute of the present Catholic Action in Poland, CA is ,an association of lay Catholics, who in more organized form cooperate with hierarchy of the Church in its apostolic mission." Present Catholic Action, just like the former organization, leads activities in many fields of social life: education, culture, charity or business. Some members of Catholic Action in Poland are involved in politics too. After the elections of 2015 to the Polish parlament entered 23 members of CA, including its president Halina Szydełko. ${ }^{2}$ Thus, the organization based on the pre-war Catholic Action has become an important center of lay people, which influence politics in the contemporary Poland.

\section{Definition and beginnings of Catholic Action}

Catholic Action is actually not well known in Poland as it was before the II World War. For the majority of Polish people CA seems to be something new. Only a small part of society knows that the organization of the laity has already long tradition in the world.

The name of Catholic Action appeared in Polish language because of Italian translation of pre-war organization called l'Azione Cattolica. Today Catholic Action is defined as "assembly of lay Catholics which in organized way cooperate directly with hierarchy of the Catholic

Ibidem. 
Church". In this way Catholic Action is characterized by its statute, ${ }^{3}$ which was approved in 1996.

There are several definitions of Catholic Action. Many authors describe it as apostolic activity. They point its sources in the beginnings of the Church. For laity specialist Eugeniusz Weron, that kind of action is connected with history of the Church. ${ }^{4}$ In the similar way defines it Stanisław Krajski. According to his opinion, Catholic Action in this meaning exists since the beginning of Christianity. ${ }^{5}$ Krajski appoints that apostolic activity has evolved, although an organization appeared in the first years of XX century. Pope Pio XI also characterized Catholic Action as not a new thing, but as ancient as the Church is. In opinion of Eugeniusz Weron forms and meaning of Catholic Action were transforming during last years. According to his present definition, Catholic Action is an organized activity of the Catholic laity. ${ }^{6}$

The engagement of lay Catholics in apostolic activity started to have a similar form to present Catholic Action after the French Revolution. As a result of cancelling by the state Church institutions and organizations, Catholics started to take defending initiatives. That time Pio Bruno de Lanteri started to create assemblies called The Catholic Friendships. Another Italian, priest Vincenzo Pallotti in 1835 founded The Union of Catholic Apostolate. Similar ideas started to be manifested among Catholics in West Europe. That time Lancordaire in France and Newman in England were preaching about necessity of the laity apostolic activity in all society.

Process of big development of various Catholic activities and organizations started to be more visible since 1848 till 1860. During that time in France has been founded La Ligue Catolique, in Belgium - L'Union Catolique, and in England - Catholic Union. Similar organizations appeared also in Germany (Katholischer Verein), in Switzerland (Piusverein) and in Spain (Asociacion de Catolicos). At that time there was founded first Catholic organizations with social and political profiles. Their main task was to defend weak social groups and to react against restrict law which had limited Church influence in politics. That tendency was represented by Bishop Ketteler, Cardinal Gibbons and Cardinal Manning. They were suggesting to the Church to keep more open attitude to the world. All of these ideas had strong influence to

$3 \quad$ Statut Akcji Katolickiej w Polsce, wstęp, [in:] E. Weron, Jak zaktadać Akcje Katolicka, Poznań 1996, p. 71.

$4 \quad$ E. Weron, Budzenie olbrzyma, Poznań 1995, p. 221

$5 \quad$ S. Krajski, Akcja Katolicka ostatnia szansa dla Polski, Warszawa 1995, p. 30

6

E. Weron, Budzenie..., p. 221 
the official preaching of Vatican. One of its fruit was encyclical of Pope Leon XIII "Rerum novarum", published in $1891 .^{7}$

Two years after "Moto Proprio", in 1905 Pope Pio X pointed theological and organizational bases of Catholic Action in encyclical "Il fermo proposito". That document had created ground for many Catholic movements, which were transformed afterwards to Catholic Action. ${ }^{8}$ "ll fermo proposito" was a base for four Italian associations, independent one from another. They were founded just after publishing of the encyclical. Unione Popolare was concerned on culture, Unione Economico-Scociale - social affairs, and Unione Elettorale - political elections. The fourth one, which was gathering young adults, was called Societa della Gioventii Cattolica Italiana. It was not easy to arrange work of all associations and coordinate theirs activities. Soon, during and after the First World War, problems started to be more visible and the first four unions were competing each other. That organizational chaos could not bring under control even Pope Benedict $\mathrm{XV}$, who had been animating some Church organizations to improve them. Just Pope Pio XI, who had been elected in 1922, got under control these organizations of lay Catholics. ${ }^{9}$

In 1922 Pope Pio XI announced his first encyclical "Ubi Arcano Dei". He defined there essence, aims and idea of structures of Catholic Action. Apart of that, Pio XI obliged through this document episcopates of some countries to found Catholic Action. The Pope suggested to adapt Catholic Action structures to local needs and conditions. ${ }^{10}$ In his opinion Catholic Action was ,participation of lay people in apostolic duties [...] to defend religious and moral values and to develop social action under leadership of the Church hierarchy for renewing Catholic life of families and society." 11

In 1923 Pio XI approved statutes of Italian Catholic Action. The organization was created by this papal confirmation, and had four state associations of men, women, young men and young women. Such structure was based on four states called "columns". To the Italian Catholic Action belonged as well academic organization FUCI. Afterwards its structures joined Catholic Action of Children.

The Italian fascist regime of Benito Mussolini was distanced to the new Catholic organization. Duce and his collaborators were treating

$7 \quad$ Cz. Strzeszewski, Katolicka nauka społeczna, Warszawa 1985.

$8 \quad$ S. Krajski, Akcja Katolicka..., p. 30.

$9 \quad$ E. Weron, Budzenie..., p. 223.

10 B. Łoziński, Akcja Katolicka, [in:] „Biuletyn KAI” no 24, 23.08.1994, p. 14-15.

11 S. Krajski, Akcja Katolicka..., p.31. 
it as a new rival on the ground of youth and children education. The first step to limit it was outlawing of the Italian Catholic scout organization in 1927. Four years later Italian authorities decided to interdict youth Catholic Action. Government accused it for arranging antigovernmental activities. The Pope was trying to counteract against that limitations made by Mussolini regime. As a sign of protest Pio XI published in 1931 encyclical "Non abbiamo bisogno"12. In that difficult time fot the Church Catholic Action successfully kept legality of its existence, but it had to withdraw social and political activities. In another countries ruled by fascist or communist governments Catholic Action organizations met with obstacles and even persecutions from authorities. The structures of Catholic Action had to face that time with difficulties in Germany, Spain and Mexico. ${ }^{13}$

The period of the II World War and first years of peace brouhgt stagnation for Catholic Action. The organization was systematically renewing itself. During nine years after the war the Italian Catholic Action gained almost five hundred thousand of new members. The organization was arranging electoral activities, solving political problems, and as well accomplishing its religious aims there. For instance the French Catholic Action was responsible for different tasks during that period. In France leaders of the laity organization put more attention to secular activities than to apostolic mission. Already in the 1950s French organizations of laity became much weaker. ${ }^{14}$

Very important event for Catholic Action was the Catholic Church Council, called Vaticanum Secundum. Decisions of the council, which took place in Rome between 1963 and 1965, changed a face of Catholic Action. The organization lost its privileged position in the Catholic Church. Since Vaticanum II CA has started to be equal to other lay associations. Bishops and cardinals abolished during the council obligation of a special mandate for Catholic Action. This privilege had before distinguished Catholic Action from other Catholic organizations. ${ }^{15}$

Although Vaticanum II changed CA the Catholic Church was still inviting to participate in its structures. The Council decree of laity apostolate encouraged priests and lay Catholics who had been cooperating with CA to collaborate also with the other forms of lay apostolate

\footnotetext{
12 Roman Catholic encyclical "Non abbiamo bisogno", 29 June 1931.

13 E. Weron, Jak zakładać Akcję Katolicka, Poznań 1996, p. 12.

14 M. Przeciszewski, Akcja Katolicka, [in:] „Biuletyn KAI” no 24, 23.08.1994, p. 19-21.

15 E. Weron, Jak zakładać..., p. 13.
} 
in the Church. The document contained conditions to fullfill to be worthy of the name "Catholic Action".

The first condition was to accomplish apostolic aim of the Church by its work. According to the second, lay people must bring to organization experience and responsibility for leadership, the third - lay people act unified as an organism, and the fourth - lay people act under leadership of the Church hierarchy, which can confirm that cooperation by giving mandate. ${ }^{16}$

Vaticanum II opened a new page in the history of Catholic Action, but from the other hand made it weaker. Transformation of statutes and structures of the organization created some problems. In most countries people became more distanced to CA. In consequence number of its members started to decrease. Many of them joined new movements of the Catholic Church. Just in the 1970s Catholic Action became stronger, as a effect of policy of Paul VI and John Paul II. Both of them were promoting that organization by actions and speeches. In 1993 John Paul II gave to the Polish bishops ideia to reactivate Catholic Action in their own country. ${ }^{17}$

\section{Forms of Catholic Action}

Catholic Action from its beginnings has been an organization without one common structure and after Vaticanum II it gained some new forms. It has acted on the five continents, having various shapes. Even though there are four main models of that organization, but Catholic Action depends of local conditions and level of involvement of the laity in apostolate. The Catholics experience of lay activities is very important too.

Selection of Catholic Action form was determined by involvement of intellectuals in life of Catholic community. In countries like Poland or Italy, where intelligentsia has abandoned during decades workers and farmers in the Church, hierarchy decided to make stronger position of ecclesial assistant. In countries, where intellectuals had not left the Church - like in Germany - bishops made decision to give to lay people more freedom in theirs choices and activities. Nowdays the position of the ecclesial assistant is not very powerful there.

The Italian structure of Catholic Action - first organization in the world - was an example for countries like Poland, the Netherlands, Spain and some others in Latin America. This type is called "uniform"
$16 \quad$ B. Łoziński, Akcja..., p. 14-15.
17 E. Weron, Jak zakładać..., p. 13. 
model. Lay people are gathered in one organization there, although it has four natural divisions, according to age and sex: men, women, male youth and female youth. Sometimes group of children or some professions like intellectualists, workers or farmers can also joint that structure. That kind of organization has usually acted on diocesan and parish level, where CA structures has been controlled by a general institution.

According to another conception, Catholic Action can be a mixed theology organization. There are two realities inside CA: "uniformed" structure and "specialized" structure, which includes professional organizations. Thanks to that solution the Church can enter into various societies and groups.

The third kind of Catholic Action is a model of "federation". Such a structure works in the Philippines, where after Vaticanum II there have existed twelve Catholic organizations independent one from other. This form is typical for some other Asian and African countries too.

Another model of Catholic Action was founded in Germany, where $\mathrm{CA}$ acts as a distinct organization only in Bavaria. Other German Catholic movements and associations are gathered in a type of Catholic Action only during Catholic Council called "Katholikentag". This kind of meetings used to be organized every two years. The Episcopal of Catholic Church in Germany is a patronage of "Katholikentag".

\section{Pre-war Catholic Action in Poland}

The beginning of Catholic Action in Poland is connected with activity of some Catholic organization, which had been existed during the time of the Partitions of Poland. After getting independence in 1918, one of the most active organizations in Poland was Catholic League. Its structures and charisma were very similar to future Polish Catholic Action. Catholic League was created in 1920 in Poznań. Six years later structures of that organization were founded in Warsaw too.

The most decisive moment for the beginnings of Catholic Action in Poland was creation of a founding comission by Polish Episcopate a commission for Catholic Action in September 1928. Among members of that group were: Cardinal August Hlond, Cardinal Aleksander Kakowski, Archbishop Adam Sapieha and Bishop Andrzej Szeptycki. Bishop Stanislaw Adamski jointed them two years later. In April 1930 the commission made important decision to found the Polish Catholic Action. Its structures were based on the uniform model of CA, which was confirmed afterwards by statute. That document was approved 
soon by Pio XI - on 27 November 1930 - who was very interested in process of creating new organization in Poland. Before the Pope confirmed only a statute of the Italian Catholic Action. These two organizations were very similar to each other. The Polish Catholic Action was based on the Italian pattern. Peasant character of Catholicism in Poland was one of motives to follow that way. There were simple religion forms in Italy and as well lack of intelligentsia among Catholics. Similar conditions in Poland helped to follow the Italian model of Catholic Action. Then the Polish Church hierarchy decided to keep in the new organization the ecclesial assistant.

On 24 November 1930 Cardinal August Hlond brought into being General Institute of Catholic Action (NIAK). First its president became Bishop Stanislaw Adamski. That Institute, situated in Poznan, was established on the top of Catholic Action structure. Since 1930 till 1932 ordinaries of diocese launched Diocesan Institutes of Catholic Action (DIAK). They were intermediate structures between NIAK and parish (PAK) or deanery (DAK) organizations of Catholic Action. Process of creating the Polish Catholic Action was finished on 1 August 1934. The government of Poland established that day as deadline for bishops to inform about final number of associations in dioceses. ${ }^{18}$

In 1934 bishops decided that Catholic League must joined structures of Catholic Action, but the hierarchy of the Polish Church did not specify any organizations. Then there were various movements and associations which belonged to it in dioceses. In that period CA was joined by Catholic Society of Polish Workers, Association of Catholic Academic Youth "Odrodzenie", Association of Polish Youth and Catholic Association of Polish Women. ${ }^{19}$

Catholic Action was founded in Poland in Greek-Catholic Church too. Its General Institute of Catholic Action with headquarter in Lvov was established in 1934. In that city was acting also Catholic Action of Armenian rite. Its structures were linked with General Institute of Catholic Action in Poznań. ${ }^{20}$

In June 1934 the Polish Episcopate decided to unify all associations belonging to Catholic Action. Bishops standardized structure of that organization, which became based on four unions called "columns": Catholic Union of Men (KZM), Catholic Union of Women (KZK), Catholic Union of Male Youth (KZMM) and Catholic Union of Female

$18 \quad$ K. Jeżyna, Akcja Katolicka w II Rzeczpospolitej, Lublin 1996, p. 37.

19 W.Zdaniewicz,Akcja Katolickaw II Rzeczpospolitej, [w:]Akcja Katolicka dzisiaj, Ząbki 1996, p. 71. 
Youth (KZMZ). The structures of Catholic Action appeared also in the Polish army.

The "columns" were existed beside institutes as a second part of Catholic Action. Their members were associations, which were supposed to act in dioceses: Catholic Association of Men (KSM), Catholic Association of Women (KSK), Catholic Association of Male Youth (KSMM) and Catholic Association of Female Youth (KSMZ). ${ }^{21}$

The third part of Catholic Action in Poland was group of supple- theology mentary associations like Apostolate of Prayer, third convents and rosary circles. All these organizations were freely connected with each another.

According to the statutes of the Polish Catholic Action, its institutes had to take care of associations, while associations were supposed to educate theirs own members. The main goal of Catholic Action in Poland was to prepare lay people to individual and group apostolate and to propagate Catholic values in every sphere of life. More precisely it was written in the main statute and statutes of associations-members of Catholic Action. According to these documents the organization was supposed to investigate needs of the Catholic life and methods to realize their own program. Other task of the Polish Catholic Action was to create initiatives among Catholics and care about correct public opinion. ${ }^{22}$

Although the Polish Catholic Action was created to care about religious life, according to its statute, the organization was supposed to involve itself in social matters, including unemployment and poverty.

Catholic Action in Poland was realizing its tasks by various methods: externally and internally. First area was more connected with spiritual activities, like a prayer, retreats and pilgrimages.$^{23}$ Internal activity of CA was manifesting itself by charity actions and some courses: economic, fashion or hygiene. Members of the organization were creating libraries, common rooms, sport and military circles. During holidays they were organizing youth trips or summer camps too. Other tasks of the Polsih Catholic Action were publishing and education. The organization was editing some newspapers like: "Ruch Katolicki", "Na Wyżyny", "Zjednoczenie" and "Przyjaciel Młodzieży". The Polish Catholic Action was publishing books too.

Since 1935 some members of Catholic Action had became involved in creating folk universities. The idea was to prepare Catholic social

\footnotetext{
$21 \quad$ E. Weron, Jak zaktadać..., p. 17.

22 E. Weron, Budzenie..., p. 229.

23 W. Zdaniewicz, Akcja Katolicka w II Rzeczpospolitej..., p. 77-78.
} 
movement in Polish villages. Such collages were founded in Ujezdna, Wąchock and Katowice.

The first years of Catholic Action in Poland were marked by some organizational difficulties. Nevertheless number of members of the new laity organization was successfully growing. There were 500 thousands people in its structures in 1936. Three years later the Polish Catholic Action had already 750 thousand members. Pre-war organization showed the most dynamical forms of activity in area of Poznan, Warsaw, Silesia and in archdiocese of Krakow.

Social composition of the Polish Catholic Action was very various. Although it had strong influence among farmers, but many of CA elites were originated from clergy, landed gentry and intelligentsia too.

The II World War stopped activity of the Catholic Action in Poland. It crossed out that organization from the list of Polish associations for many years. After the end of the war it was not possible to reactivate structures of CA. According to communist government decree, published on 5 August 1948, Catholic Action could not start its work anymore. ${ }^{24}$

Summing up the above reflections, it should be noted that the reactivation of Catholic Action in Poland would not be possible without the pre-war structures of this organization of lay Catholics. Therefore, two decades ago, during the rebirth of CA, which was the fulfillment of John Paul II's wish, the knowledge of the teaching of the Church in relation to this short-lasting and mass organization, as well as the forms in which it acted in the world. In case of the Polish prototype there was important to follow Popes ideas and acts about Catholic Action and as well to imitate the first AK model, launched in Italy. A common figure for these organizations was the Church assistant, who was a liaison between lay people and the Church hierarchy.

\section{KU PRZEDWOJENNEJ AKCJI KATOLICKIEJ. TWORZĄC NOWE NA TRADYCYJNYCH PODSTAWACH}

Reaktywacja Akcji Katolickiej (AK) w Polsce, która skończyła swoją faktyczną działalność w 1939 r., byłaby mało realna bez przedwojennych struktur tej organizacji zrzeszającej katolików świeckich. Wprawdzie przerwa w istnieniu tej organizacji w Polsce trwała blisko 60 lat, ale dawna forma działalności, program i liczne jej dzieła zachęciły polski Kościół, z inicjatywy Jana Pawła II, do odrodzenia tego podmiotu. W niniejszym artykule ukazano w zarysie podstawy

$24 \quad$ M. Przeciszewski, Akcja..., p. 17-18. 
ideologiczne tworzenia pierwszej Akcji Katolickiej na świecie. Zaprezentowano także jej główne formy organizacyjne, przedstawiając równocześnie podobieństwo struktur przedwojennej organizacji katolików świeckich w Polsce do jej włoskiego pierwowzoru. W ostatniej części opracowania zarysowano przebieg tworzenia struktur przedwojennej Akcji Katolickiej w Polsce, podstawy prawne jej funkcjonowania oraz obszary działalności. Wprawdzie na świecie po Soborze Watykańskim II, nastąpiło inne postrzeganie laikatu, a jego rola w Kościele wzrosła, ale przedwojenna Akcja Katolicka stała się w Polsce bazą Pastoral do tworzenia nowej organizacji. Reaktywowana AK przybrała dosyć tradycyjny model, z zachowaniem instytucji asystenta kościelnego jako łącznika świeckich z hierarchią Kościoła.

Słowa kluczowe: Kościół Katolicki, Akcja Katolicka, Polska, laikat, Stolica Apostolska.

\section{Bibliography:}

1. Akcja Katolicka - 20 lat później, [in:] Katolicka Agencja Informacyjna, 22.11.2015.

2. Jeżyna K., Akcja Katolicka w II Rzeczpospolitej, Lublin 1996.

3. Krajski S., Akcja Katolicka ostatnia szansa dla Polski, Warszawa 1995.

4. Łoziński B., Akcja Katolicka, [in:] „Biuletyn KAI” no 24, 23.08.1994.

5. Przeciszewski M., Akcja Katolicka, [in:] „Biuletyn KAI” no 24, 23.08.1994.

6. Statut Akcji Katolickiej w Polsce, wstęp, [in:] E. Weron, Jak zaktadać Akcję Katolicka, Poznań 1996.

7. Strzeszewski Cz., Katolicka nauka społeczna, Warszawa 1985.

8. Weron E., Budzenie olbrzyma, Poznań 1995.

9. Weron E., Jak zakładać Akcję Katolicka, Poznań 1996.

10. Zdaniewicz W., Akcja Katolicka w II Rzeczpospolitej, [w:] Akcja Katolicka dzisiaj, Ząbki 1996. 